\title{
Serum Levels of Insulin-Like Growth Factor-I, Thyroid Hormones and Skeletal Muscle Fiber Size in Castrated Lambs with and Without Androgen Treatment
}

\author{
${ }^{1}$ Bani Ismail, Z., ${ }^{1}$ O.M. AL-Ababneh and ${ }^{2}$ M.B. AL-Zghoul \\ ${ }^{1}$ Department of Veterinary Clinical Sciences, \\ ${ }^{2}$ Basic Veterinary Sciences, \\ Faculty of Veterinary Medicine, Jordan University of Science and Technology, \\ Irbid 22110, Jordan
}

\begin{abstract}
Twelve, intact male lambs, 1-2- weeks old, were divided into 3 groups, Group W (4 lambs) were castrated at age less than 1 month, group WT (4 lambs) were castrated at the same age and treated with testosterone and group R (4 lambs) were left intact and served as control. Testosterone Propionate replacement was administered intramuscularly at a dose of $12.5 \mathrm{mg}$ started at the day of castration and continued every 2 days for 21 days, then at a dose of $25 \mathrm{mg}$ every 2 weeks until slaughter. Serum insulin-like growth factor-1, T3 and T4 concentrations were measured using ELISA. Lambs were slaughtered at 8 months of age and semitendinosus and splenius muscles fiber areas were measured using digital image technique. In WT and R groups, IGF-I concentrations were significantly higher $(\mathrm{p}<0.05)$ at 4 and 8 months compared to IGF-I levels in group W. Serum T3 concentrations were significantly lowest in group R compared to groups W and WT. Serum levels of T4 were not significantly affected by age in younger lambs, although it was significantly higher in group $\mathrm{R}$ at 6 and 8 months of age. In group R, splenius muscle fiber area $\left(1458 \pm 193 \mathrm{um}^{2}\right)$ was significantly higher $(\mathrm{p}<0.05)$ than that of groups W and WT while the muscle fiber area of the semitendinosus muscle was not significantly different among all groups.
\end{abstract}

Key words: Castration, muscle growth, awassi lambs, IGF-1, thyroid hormones

\section{INTRODUCTION}

Growth have been found to be influenced by many endocrine hormones such as androgens, growth hormone $(\mathrm{GH})$, Insulin, Insulin-like Growth Factors (IGFs) and thyroid hormones ${ }^{[8]}$. It has been found that male animals possess greater muscle in the neck and forequarters than females and that intact male grow faster, utilize feed more efficiently and have less fat per carcass than castrated males and females ${ }^{[2,10]}$. This sexual dimorphism is attributed to the presence of androgens, IGF-1 and $\mathrm{GH}^{[8]}$. In addition, it was found that myostatin (a muscle growth inhibitor) expression in muscles of intact males is lower than females and castrated animals. It was found that testosterone treatment increases serum concentrations of IGF-I, suggesting that testosterone modulates the IGF-I action by increasing local IGF-I production in muscles ${ }^{[2,3,9]}$.

Thyroid hormones, triiodothyronine (T3) and thyroxin (T4) have a major role in differentiation, growth and development of skeletal muscle in utero, although their mechanism of action is poorly understood $^{[5]}$. Studies have shown that T3 stimulates transcription of myogenic genes and induces differentiation of myoblasts ${ }^{[5]}$. On turn, these effects may direct or involve alterations in the local production of growth factors such as IGF-I and IGF-II ${ }^{[5]}$. In addition, it has been found that $\mathrm{T} 4$ potentiates growth hormone action in many tissues and is responsible for increased musclization in callipyge sheep ${ }^{[11]}$.

This experiment was undertaken to determine whether male Awassi sheep possess sexual dimorphism in muscle growth by determining muscle fiber area, to identify which muscles have greater responsiveness to testosterone treatment and to determine serum levels of IGF-1, T3 and T4 in intact and castrated males with and without testosterone treatment.

\section{MATERIALS AND METHODS}

Animals: Twelve, healthy, male Awassi lambs (1-2 weeks old $10.6 \pm 2 \mathrm{Kg} \mathrm{BW}$ ) were selected and assigned

Corresponding Author: Zuhair A. Bani Ismail, Department of Veterinary Clinical Sciences, Faculty of Veterinary Medicine, Jordan University of Science and Technology Irbid 22110, Jordan Tel: $962-2-7201000$ ext. 22018 Fax: 962-2-7201081 
randomly to 3 groups of 4 animals each. In group 1, lambs were castrated at 2 weeks of age and were not supplemented with testosterone (W), group 2, lambs were castrated at 2 weeks of age and were supplemented With Testosterone (WT) and in group 3, lambs were not castrated and served as control (R). Each lamb was udder-fed freely from its own mother until weaning ( 2 months of age). After weaning, lambs were housed separately and offered a barely-based diet containing $16 \%$ crude protein.

Testosterone dosages and interval: Testosterone Propionate (Primoteston ${ }^{\circledR}$ Depot, Schering AG, Germany) replacement was administered intramuscularly in a vehicle of corn oil (9:1) at a dose of $12.5 \mathrm{mg}$ started at the day of castration and continued every 2 days for 21 days, then at a dose of 25 mg every 2 weeks until slaughter.

Blood sample collection: Five to seven milliliters of whole blood were collected aseptically from the jugular vein using disposable needles and vacutainer tubes before castration and at 2, 4, 6 and 8 months of age. Serum was obtained by allowing the blood to clot in room temperature,entrifugation and collection in a special epindorf tubes. Serum samples were stored at $20^{\circ} \mathrm{C}$ until used. Serum testosterone levels were determined using a commercially available enzyme immunoassay test kit (BioCheck Inc, USA).

Live animal weights: Animals were weighed before castration and every one month until slaughter. Weights were recorded for analysis. Growth rates (gm/day) were calculated from birth to slaughter.

Slaughter: Animals were humanely slaughtered at 8 months of age.

Measurement of muscle fiber size: Approximately 0.5 -cubic centimeter, cross sectional tissue samples from the splenius and semitendinosus muscles were obtained immediately following slaughter and were preserved in $10 \%$ buffered formalin until further processing. Histological processing of the muscle tissue samples was performed using (Histokinette Processor Leica, Germany), after tissue fixation completed they were transferred to be embedded in blocks of paraffin and when the blocks were ready $5 \mu \mathrm{m}$ tissue sections using microtome (Biocut Leica, Germany).The sections were transferred on microslides and left to dry. Muscle sections then were stained using Periodic Acid Schiffs Stain (PAS).

Muscle fiber area $\left(\mu \mathrm{m}^{2}\right)$ was measured by sampling 10 random sections per slide in the central region of the splenius and semitendinosus muscles. The muscle histological sections were viewed at $40 \times$ magnifications. All assessments were performed using a DMBA200 Motic microscope (Motic Instruments Inc., China). The images were captured by a Motic MCCamera (Motic Instruments Inc., China) coupled to a personal computer. Motic image plus 2.0 software (Motic Instruments Inc., China) was used for measurements of muscle fiber area and calculated by statistical ANOVA test. Pictures at $40 \times$ magnifications are included. To further confirm our results, we used image analysis software, NIH Image-J program, http://rsb.info.nih.gov/ij/download.html.

Serum hormone level determinations: Serum IGF-1 (Diagnostic Systems Laboratories, USA), T3 and T4 (Biocheck Inc, USA) levels were determined using a commercial ELISA kits according to manufacturer recommendations.

Statistical analysis: All the data are shown as in mean \pm SD. One way ANOVA was used to compare between different parameters at different ages in all groups. The means of serum levels of IGF-I, T3, T4 and weights were compared separately using least significant difference as a mean separation test. The same test was used to compare the muscle fiber area for the splenius and semitendinosus muscles in all groups. Correlation coefficients ( $\mathrm{r}$ values) were calculated and if the absolute value was greater than 0.5 , it was considered a significant correlation. Differences were considered significant at $\mathrm{p}<0.05$.

\section{RESULTS}

The mean \pm SD of serum levels of IGF-1 in different groups at various ages are summarized in Table 1 . In group W, IGF-1 levels varied widely between $86 \pm 49$ ng $\mathrm{mL}^{1}$ at 4 months of age to $(578 \pm 480 \mathrm{ng} \mathrm{mL})$ at 2 months of age.

In group WT, the mean serum IGF-1 levels peaked at 8 months of age $\left(1128 \pm 275 \mathrm{ng} \mathrm{mL}^{1}\right)$ and were lowest at 4 months of age $\left(490 \pm 90 \mathrm{ng} \mathrm{mL}^{1}\right)$. In group R, serum IGF-1 had a biphasic pattern with peaks at 4 and 8 months of age $\left(474 \pm 116\right.$ and $1630 \pm 80 \mathrm{ng} \mathrm{mL}^{1}$, respectively). In WT and R groups, IGF-I concentrations were statistically significant $(p<0.05)$ at 4 and 8 months compared to IGF-I levels in group W while IGF-I levels were significant $(p<0.05)$ in group $R$ compared to groups W and WT at 6 months of age. There was a positive correlation between IGF-I concentrations and growth rate in group $\mathrm{R}$ and to a lesser degree in group WT $(r=+0.90$ and $r=+0.75)$, respectively. There was an effect of age on IGF-1 
Am. J. Applied Sci., 6 (3): 518-522, 2009

Table 1: Mean \pm SD of serum IGF-I concentration $\left(\mathrm{ng} \mathrm{mL}^{-1}\right)$

\begin{tabular}{lllll}
\hline & Age (Months) & & \\
& - & & \\
Groups & 2 & 4 & 6 & 8 \\
\hline W & $578 \pm 480^{\mathrm{a}}$ & $86 \pm 49^{\mathrm{b}}$ & $119 \pm 32^{\mathrm{c}}$ & $452 \pm 210^{\mathrm{b}}$ \\
WT & $471 \pm 26^{\mathrm{a}}$ & $490 \pm 90^{\mathrm{a}}$ & $660 \pm 110^{\mathrm{a}}$ & $1128 \pm 275^{\mathrm{a}}$ \\
R & $362 \pm 125^{\mathrm{a}}$ & $474 \pm 116^{\mathrm{a}}$ & $246 \pm 118^{\mathrm{b}}$ & $1630 \pm 80^{\mathrm{a}}$ \\
\hline
\end{tabular}

Different superscript letters in the same column are statistically significant $(\mathrm{p}<0.05) . \mathrm{W}=$ wethers, $\mathrm{WT}=$ wethers with testosterone treatment, $\mathrm{R}=$ rams

Table 2: Mean \pm SD of serum T3 concentration ( $\mathrm{ng} \mathrm{mL}^{-1}$ )

\begin{tabular}{lllll}
\hline & Age (Months) & & \\
& - & & & \\
Groups & 2 & 4 & 6 & 8 \\
\hline W & $3.0 \pm 0.1^{\mathrm{a}}$ & $2.1 \pm 0.7^{\mathrm{a}}$ & $3.5 \pm 0.6^{\mathrm{a}}$ & $3.4 \pm 0.02^{\mathrm{a}}$ \\
WT & $2.7 \pm 0.1^{\mathrm{a}}$ & $1.9 \pm 0.1^{\mathrm{a}}$ & $2.9 \pm 0.5^{\mathrm{a}}$ & $3.1 \pm 0.2^{\mathrm{a}}$ \\
R & $1.9 \pm 0.7^{\mathrm{b}}$ & $1.9 \pm 0.0^{\mathrm{a}}$ & $1.7 \pm 0.14^{\mathrm{b}}$ & $2.1 \pm 0.33^{\mathrm{b}}$ \\
\hline
\end{tabular}

Different superscript letters in the same column are statistically significant $(\mathrm{p}<0.05) \mathrm{W}=$ wethers, $\mathrm{WT}=$ wethers with testosterone treatment, $\mathrm{R}=$ rams

concentration in groups $\mathrm{WT}$ and $\mathrm{R}(\mathrm{p}<0.05)$. There was a positive correlation between IGF-I, T3 and T4 concentrations in group $\mathrm{R}$.

The mean \pm SD of serum levels of $\mathrm{T} 3$ in different groups at various ages are summarized in Table 2 . Before castration, all animals had similar T3 concentrations. In group $\mathrm{W}$, serum $\mathrm{T} 3$ concentrations peaked at 6 months of age $\left(3.5 \pm 0.6 \mathrm{ng} \mathrm{mL}{ }^{1}\right)$. In group WT, serum T3 concentrations peaked at 8 months of

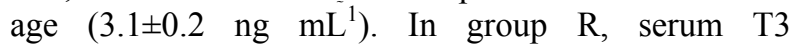
concentrations peaked at 8 months of age $(2.1 \pm 0.33 \mathrm{ng}$ $\mathrm{mL}^{1}$ ). Serum T3 concentrations were significantly lowest in group R compared to groups W and WT at most of sampling times. Group WT had intermediate serum levels of $\mathrm{T} 3$ in sampling times. There was a negative correlation between the concentration of $\mathrm{T} 3$ and age in group R. Tes00tosterone treatment resulted in marginally reduced T3 concentration in group WT.

The mean $\pm \mathrm{SD}$ of serum levels of $\mathrm{T} 4$ in different groups at various ages are summarized in Table 3. Serum T4 concentration at one month of age in all lambs and before castration was $\left(12 \pm 1.1 \mathrm{ug} \mathrm{dL}^{1}\right)$. In groups $\mathrm{W}$ and $\mathrm{WT}$, serum T4 concentrations peaked at 6 months of age $\left(14.8 \pm 0.8\right.$ and $\left.14.60 \pm 0.5 \mathrm{ug} \mathrm{dL}^{1}\right)$ respectively. In group $\mathrm{R}$, the serum $\mathrm{T} 4$ concentrations peaked at 8 months of age $\left(20 \pm 7.70 \mathrm{ug} \mathrm{dL}{ }^{1}\right)$. Higher serum levels of T4 were statistically significant in group $\mathrm{R}$ at 6 and 8 months of age compared to its levels in groups W and WT. In general, serum levels of T4 were not significantly affected by age in all groups until months 6 and 8 months of age in groups WT and R where its concentrations were significantly higher.

Animal weights were recorded every 1 month and immediately before slaughter Table 4 . The mean weight
Table 3 Mean \pm SD of serum T4 concentration $\left(\mu \mathrm{g} \mathrm{dL}^{-1}\right)$

\begin{tabular}{|c|c|c|c|c|}
\hline \multirow[b]{2}{*}{ Groups } & \multicolumn{4}{|c|}{ Age (Months) } \\
\hline & 2 & 4 & 6 & 8 \\
\hline $\mathrm{W}$ & $12.0 \pm 0.3^{\mathrm{a}}$ & $12.6 \pm 0.6^{\mathrm{a}}$ & $14.8 \pm 0.8^{b}$ & $13.6 \pm 2.3^{b}$ \\
\hline WT & $10.4 \pm 0.8^{\mathrm{a}}$ & $12.8 \pm 0.2^{\mathrm{a}}$ & $14.6 \pm 0.5^{b}$ & $12.4 \pm 1.5^{\mathrm{b}}$ \\
\hline $\mathrm{R}$ & $11.4 \pm 2.4^{\mathrm{a}}$ & $11.7 \pm 1.0^{\mathrm{a}}$ & $19.7 \pm 2.7^{\mathrm{a}}$ & $20.1 \pm 7.7^{\mathrm{a}}$ \\
\hline
\end{tabular}

Different superscript letters in the same column are statistically significant $(\mathrm{p}<0.05) . \mathrm{W}=$ wethers, WT $=$ wethers with testosterone treatment, $\mathrm{R}=$ rams

Table 4 Mean \pm SD of live animal weights $(\mathrm{Kg})$

\begin{tabular}{lllll}
\hline & \multicolumn{3}{l}{ Age (Months) } & \\
Groups & 2 & 4 & 6 & 8 \\
\hline W & $13.0 \pm 1.7^{\mathrm{a}}$ & $25.0 \pm 2.3^{\mathrm{b}}$ & $30.0 \pm 4.3^{\mathrm{b}}$ & $38.0 \pm 4.3^{\mathrm{b}}$ \\
WT & $13.0 \pm 2.9^{\mathrm{a}}$ & $24.0 \pm 3.9^{\mathrm{b}}$ & $28.0 \pm 4.8^{\mathrm{b}}$ & $37.0 \pm 6.2^{\mathrm{b}}$ \\
R & $13.0 \pm 4.6^{\mathrm{a}}$ & $30.0 \pm 4.9^{\mathrm{a}}$ & $37.0 \pm 1.4^{\mathrm{a}}$ & $49.0 \pm 1.8^{\mathrm{a}}$ \\
\hline
\end{tabular}

Different superscript letters in the same column are statistically significant $(\mathrm{p}<0.05) \mathrm{W}=$ wethers, WT $=$ wethers with testosterone treatment, $\mathrm{R}=$ rams

of all animals before the start of the study was $(10.6 \pm 2$ $\mathrm{kg})$. The highest daily weight gain was reported in group R (19.90 gm/day) followed by group W and the lowest weight gain was in group WT. There was a significant difference in weight gain $(p<0.05)$ between group R and groups $\mathrm{W}$ and $\mathrm{WT}$ and no significant difference between group W and group WT. At slaughter, the highest weight recorded was in group $\mathrm{R}$ $(49 \pm 1.8 \mathrm{~kg})$ and the lowest was in group WT $(37 \pm 6 \mathrm{~kg})$. Final live weight was significant $(p<0.05)$ in group $R$. There were no significant differences in live weights in groups W and WT.

In group $\mathrm{W}$, splenius muscle fiber area was significantly lower $(p<0.05)$ than other groups $\left(797 \pm 100 \mathrm{um}^{2}\right)$. In group WT, splenius muscle fiber area was the second highest among groups (1075 130 $\mathrm{um}^{2}$ ) and it was significantly higher than that of group $\mathrm{W}$, but lower than that of group $\mathrm{R}(\mathrm{p}<0.05)$. In group $\mathrm{R}$, splenius muscle fiber area $\left(1458 \pm 193 \mathrm{um}^{2}\right)$ was significantly higher $(\mathrm{p}<0.05)$ than that of groups $\mathrm{W}$ and WT.

The muscle fiber area of the semitendinosus was similar in all groups. Although it was higher in group WT than that in other groups, there were no significant differences in muscle fiber area between all groups. The mean of semitendinosus muscle fiber area in groups $\mathrm{W}$, WT and R were $708 \pm 158,848 \pm 125$ and $700 \pm 192 \mathrm{um}^{2}$ respectively.

\section{DISCUSSION}

In the present study IGF-I serum concentrations recorded a variable mean values in all groups along the study time. Many genetic and non-genetic factors affect 
plasma IGF-I concentration including sex, birth weight, nutrition, weaning and internal parasite load. IGF-I serum concentrations in the castrated group were lower than those reported previously ${ }^{[9]}$. However, it was similar to the values reported for the intact males ${ }^{[5]}$. There were no significant differences between the castrated groups, as IGF-I is affected by sex. These results could be attributed to the very low testosterone levels in the testosterone treated group.

Serum levels of IGF-1 in rams were significantly higher than wethers with and without testosterone supplementation. In wethers with testosterone supplementation, IGF-1 levels were intermediate between $\mathrm{W}$ and R. Sexual dimorphism of IGF-1 has been reported previously at and after puberty in rams ${ }^{[9]}$. It has been reported that plasma IGF-1 levels are similar in rams and ewes before puberty ${ }^{[9]}$. These changes in plasma IGF-1 levels were also correspondent with the appearance of sex differences in live weight between rams and ewes.

Most of the study time, testosterone treated group recorded a low IGF-I serum concentrations. These results are opposite to those of Arnold et al. (1996) ${ }^{[1]}$ who reported that IGF-I plasma concentration increased in response to testosterone implantation and was significantly higher than that of wethers. This may be attributed to the very low serum testosterone concentrations in this group which may resulted because of lower testosterone dose used in this study.

In the present study, T3 serum concentrations were higher in group $\mathrm{W}$ than that in other groups. They were significantly higher than group $\mathrm{R}$ only at 6 and 8 months of age $(\mathrm{p}<0.05)$. Head et al., ${ }^{[7]}$ reported that T3 concentrations were higher in wethers than in heavier selected lambs and he related this difference to a more thyroid hormones needed to initiate the same response noticed in the selected lambs, he also mentioned that the T4 deiodination into T3 would have an additive effect on increased T3 concentrations. It was found that higher serum T3 concentrations are proportionally positive with growth in lambs ${ }^{[11]}$.

Group WT had intermediate T3 serum concentrations. This may be attributed to the intermediate activity and T3 metabolic rate ${ }^{[7]}$. It is believed that $\mathrm{T} 3$ metabolism rate affect its serum concentration $^{[7]}$. Head et $a l^{[7]}$ reported that $\mathrm{T} 3$ concentrations were lower in selected groups due to the higher T3 metabolism rate as a result of increased growth rate. Our results are in agreement with the reported patterns of T3 levels in previous reports. Our results of $\mathrm{T} 3$ serum concentrations at different ages were higher than those recorded by Head et al., ${ }^{[7]}$.
In the present study, T4 serum concentrations were in the range reported by Head et al., ${ }^{[7]}$ to the third month of age, but there after our results have been two or three times higher than those reported by Head et $a l .{ }^{[7]}$. It has been reported that $\mathrm{T} 4$ concentrations vary according to breed and affected by genetics. In this study, T4 serum concentrations recorded had no significant differences between groups along the study time. These findings are not in agreement with results of Head et al., ${ }^{[7]}$ who reported that there is significant difference in T4 between castrated and selected lambs.

The increase in animals weight gain was proportional to age in all groups. Before puberty, there was no significant difference between groups $(p>0.05)$. This could be explained by the absence of sex effect in the prepubertal period. Cui et al. ${ }^{[4]}$ reported that 4-5 months of age is a critical period of puberty and testosterone secretion. Mateescu and Thonney $(2005)^{[9]}$ reported that no sex-related differences in weight gain between rams and wethers in the prepubertal period.

In testosterone supplemented wethers, body weights only slightly approached being significantly heavier than wethers with no testosterone supplement. These results are in agreement with results of Galbraith and Berry (1994) ${ }^{[6]}$, who found that testosterone given to wethers, increased their live weight gain. The male dominance on feed consumption may result in the increased weights and the significant differences in group R weight gain over animals of other groups.

The splenius muscle is a sexually dimorphic muscle grows to a larger size with a biphasic pattern of growth $^{[2,3,9,10]}$. In group $\mathrm{W}$, splenius muscle fiber area was significantly the lowest among groups $(p<0.05)$. It has been reported that sexually dimorphic muscles had a higher expression of androgen receptors or higher androgen sensitivity ${ }^{[9]}$.

Testosterone treatment resulted in an increase in the splenius muscle fiber area in group WT. It was significantly higher than that of group $\mathrm{W}$ and significantly lower than that in group $R(p<0.05)$. The results of Arnold et al. (1997) ${ }^{[2]}$ were that both intact ram and wethers with testosterone implant had a greater splenius muscle than those of wethers in means of single muscle weight.

Sexually dimorphic muscle grow to a larger size due to testosterone effect on the muscle and on IGF-I which act positively in muscle growth ${ }^{[2,3,9,10]}$, In group $\mathrm{R}$ splenius muscle fiber area was the significantly the highest among groups $(\mathrm{p}<0.05)$, this positively indicate the effect of testosterone on muscle growth.

The semitendinosus muscle is a non-sexually dimorphic muscle $e^{[2,3,9,10]}$. In this study semitendinosus 
muscle fiber area of group $\mathrm{W}$ was significantly lower than that in group WT and $\mathrm{R}(\mathrm{p}<0.05)$.

In group WT semitendinosus muscle fiber area positively affected by testosterone treatment, these results are in agreement with results of previous reports ${ }^{[2,3,9,10]}$. Arnold et al. ${ }^{[2]}$ reported that testosterone had a combined effect on muscle growth which affected by testosterone and testosterone treatment.

\section{ACKNOWLEDGEMENTS}

Thanks to the Deanship of research at Jordan University of Science and Technology for sponsoring this research.

\section{REFERENCES}

1. Arnold, A.M., J.M. Peralta and M.L. Thonney 1996. Ontogeny of growth hormone, Insulin-like Growth Factor (IGF)-I, estradiol and cortisol in the growing lamb: Effect of testosterone. J. Endocrinol., 150: 391-399. http://cat.inist.fr/? aModele $=$ afficheN\&cpsidt $=3240541$.

2. Arnold, A.M., J.M. Peralta and M.L. Thonney, 1997. Effect of testosterone on differential muscle growth and on protein and nucleic acid concentrations in muscles of growing lambs. J. Anim. Sci., 75: 1495-1503. http://cat.inist.fr/? aModele $=$ afficheN\&cpsidt $=2686105$.

3. Brndestetter, A.M., M.W. Pfaffi, J.F. Hocquette, D.E. Gerrard, B. Picard, Y. Geay and H. Sauerwein, 2000. Effects of muscle type, castration, age and compensatory growth rate on androgen receptor mRNA expression in bovine skeletal muscles. J. Anim. Sci., 78: 629-637. http://jas.fass.org/cgi/content/abstract/78/3/629.

4. Cui, S., Y.F. Chen, H.N. Yue, Y.Q. He and A.S. McNeilly 2003. Sexual development and the effect of active immunization against GnRH in Chinese Tanyang ram lambs. Anim. Reprod. Sci., 77: 129-139. http://cat.inist.fr/?aModele= afficheN\&cpsidt $=14860979$.

5. Forhead, A.J., J. Li, R.S. Glimour, N.J. Dauncey and A.L. Fowden, 2002. Thyroid hormones and the mRNA of the GH receptor and IGFs in skeletal muscle of fetal sheep. Am. J. Physiol., Endocrinol. Metabolism, 282: E80-E86. Doi: 10.1152/ajpendo. 00284.2001. http://ajpendo.physiology.org/cgi/ content/abstract/282/1/E80.
6. Galbraith, H. and A.D. Berry, 1994. Effect of naturally occurring and synthetic androgens on growth, body composition and muscle glucocorticoid receptors in wether lambs. Anim. Prod., 58: 357-364. http://www.fao.org/agris/ search/display.do?f=./1996/v2218/GB9412063.xml ;GB9412063.

7. Head, W.A., P.G. Hatfield, D.M. Hallford, J.A. Fitzgerald, M.K. Petersen and J.N. Stellflug, 1996. Effect of selection for lifetime production of lamb weaned on hormonal factors that affect growth in targhee ewes and lambs. J. Anim. Sci., 74: 2152-2157. http://www.ncbi.nlm.nih.gov/ pubmed/8880417?dopt=Abstract.

8. Liu, J.L. and D. LeRoith, 1999. Insulin-like growth factor-i is essential for post-natal body growth in response to growth hormone. Endocrinology, 140: 5178-5184. http://www.ncbi.nlm.nih.gov/ pubmed/10537147?dopt=Abstract.

9. Mateescu, R.G. and Thonney, M.L., 2005. Effect of testosterone on insulin-like growth factor-i androgen receptor and Myostatin gene expression in splenius and semitendinosus muscles in sheep. J. Anim. Sci., 83: 803-809. http://www.ncbi.nlm.nih. gov/pubmed/15753334? dopt=Abstract.

10. Wellington, G.H., D.E. Hogue and R.H. Foote 2003. Growth, carcass characteristics and androgen concentrations of gonad-altered ram lambs. Small Ruminants Res., 48: 51-59. doi:10.1016/S09214488(03)00007-5. http://www.sciencedirect.com/ science? ob=ArticleURL\&_udi=B6TC547RRVDP-3\&_user $=2121099 \&$ rdoc $=1 \&$ fmt $=\&$ orig $=$ search\&_sort $=\mathrm{d} \&$ view $=\mathrm{c} \&$ \&version $=1 \&$ url $\bar{V}$ ersion $=0 \&$ userid $=2121099 \& \mathrm{md} 5=3 \mathrm{f} 0 \mathrm{c} 5 \mathrm{dc} 6488$ 85f2063b19ce56ff5870a.

11. Whisnant, C.S., R.S. Kline, J.C. Branum, G.M. Zaunbrecher, M.Z. Khan and S.P. Jackson, 1998. Hormonal profiles of callipyge and normal sheep. J. Anim. Sci., 76: 1443-1447. http://jas.fass.org/cgi/content/abstract/76/5/1443. 